\title{
Comparing Phonetic Complexity between Fluent and Disfluent Eojeols in Adults Who Stutter
}

\author{
HeeCheong Chon \\ Department of Speech-Language Pathology, Chosun University, Gwangju, Korea
}

Received: December 6, 2020 Revised: December 29, 2020 Accepted: January 1, 2021

\section{Correspondence:} HeeCheong Chon, PhD Department of SpeechLanguage Pathology, Chosun University, 309 Pilmun-daero, Dong-gu, Gwangju 61452, Korea Tel: +82-62-230-7857 Fax: +82-62-608-5401 E-mail: hchon@chosun.ac.kr

\begin{abstract}
Purpose: The purpose of this study was to investigate the characteristics of phonetic complexity in disfluent eojeols of adults who stutter. Therefore, phonetic complexity between fluent and disfluent [including stuttering-like disfluency (SLD) or other disfluency (OD)] eojeols was compared using two speaking tasks. Methods: Twenty-one adults who stutter performed a picture description task and a conversation task. Those speech samples were divided into eojeols, and each eojeol was classified as a "fluent eojeol" if it was perceptually fluent, an "OD eojeol" if it was produced with ODs, or an "SLD eojeol" if it was produced with SLDs. The index of phonetic complexity (IPC) and the phonological mean length of utterance (PMLU) were measured to compare phonetic complexity between the tasks and the types of eojeols. Results: The IPC was significantly the greatest in the SLD eojeol regardless of task. The IPC of the fluent eojeol was significantly greater than that of the OD eojeol. The SLD eojeol also showed significantly the greatest PMLU among the types of eojeols, and the fluent eojeol showed significantly greater PMLU than the OD eojeol. Significant positive correlations were found between IPCs and PMLUs for each eojeol no matter the task. Conclusion: When producing eojeols, greater phonetic complexity can trigger SLDs in adults who stutter, supporting the psycholinguistic aspects of stuttering.
\end{abstract}

Key Words: Disfluent eojeol, Index of phonetic complexity, Phonetic complexity, Phonological mean length of utterance, Stuttering.

\section{INTRODUCTION}

발달성 말더듬(이하 말더듬)은 아직까지 명확한 원인이 밝혀 지지 않은 말장애이다. 연구자들은 다양한 관점에서 말더듬의 원인과 진전(지속과 회복), 특성을 밝히기 위한 연구를 진행해 왔으며, 유전, 언어, 말운동통제, 환경 등과 같은 다양한 요인이 말더듬에 영향을 줄 수 있음을 보고하였다(Felsenfeld et al., 2000; Ludlow \& Loucks, 2003; Postma \& Kolk, 1993; Yairi \& Ambrose, 2005; Yairi et al., 1996). 이러한 연구결과들을 토대 로 하여 말더듬은 다요인적인 관점에서 설명되기도 한다. 즉, 하나 의 단일 요인 때문이 아니라 다양한 요인의 상호작용으로 인하여 말더듬이 시작되고 진전된다는 것이다(Smith \& Kelly, 1997).

심리언어학적인 관점에서 비유창성을 설명한 내적수정가설 (covert repair hypothesis) (Kolk \& Postma, 1997; Postma \& Kolk, 1993)은 화자가 발화를 산출하기 전에 내면적 감독과정

(c) This is an Open Access article distributed under the terms of the Creative Commons Attribution Non-Commercial License (https://creativecommons.org/licenses/by-nc/4.0) which permits unrestricted non-commercial use, distribution, and reproduction in any medium, provided the original work is properly cited. (internal monitoring process)을 통해 자신이 계획한 메시지에 음운적, 구문적, 의미적 측면의 오류가 있는지 감시하게 되며, 오류가 감지될 경우 내적으로 수정하는 과정을 거쳐 말을 산출 하게 된다고 보았다. 이때 내적으로 오류를 수정하는 과정으로 인해 비유창성이 발생한다고 주장하였다. 특히 말더듬는 사람 은 자신이 산출하고자 하는 발화의 언어형식 구성 단계(formulation stage)에서 이루어지는 음운적 부호화(phonological encoding)가 비정상적으로 느리기 때문에 음운 목표를 찾는 데 더 많은 시간이 걸리며, 음성계획(phonetic plan) 과정에서 오 류가 더 많이 발생하고 감지된다고 하였다. 따라서 이러한 오류 를 내적으로 수정하는 과정이 일반인에 비해 빈번하고 이러한 과정의 결과로 비유창성 또한 더 빈번하게 나타난다고 하였다 (Postma \& Kolk, 1993). 또한 길고 복잡한 혹은 발음하기 어려 운 발화를 산출할 때 음성계획 과정에서 더 많은 오류가 발생하 고 감지되어 비유창성 또한 증가될 것으로 예측하였다(Kolk \& Postma, 1997). 이와 관련하여 말더듬 장애의 핵심적인 자질인 '진성비유창성(stuttering-like disfluency, SLD)'과 구문적 측 면과의 관련성을 살핀 선행연구들은 말더듬 아동 및 성인의 발 
화를 분석한 결과 SLD가 발생한 발화가 유창한 발화보다 길이 가 길고 구문적으로 복잡했음을 보고하였다(Chon \& Lee, 2019; Gaines et al., 1991; Logan \& Conture, 1995). 음운적인 측면에서 $\mathrm{SLD}$ 와의 관련성을 살핀 연구들은 발화보다 낮은 언 어학적 단위인 말소리, 낱말, 어절 등을 사용하였다. 말더듬는 사람들을 대상으로 특정 말소리가 SLD 발생에 영향을 미치는 지 살펴본 선행연구들은 자음에서 $\mathrm{SLD}$ 의 빈도가 높았다고 보 고하거나(Sheehan, 1974) 모음에서 SLD 빈도가 높았다는 결 과를 보고하였다(Shin, 1996). Kwon(1991)은 말소리 발달 특성 상 후기에 발달하는 말소리에서 SLD 발생빈도가 높다고 하였 다. 최근에 말소리와 비정상적 비유창성 출현과의 관련성을 워 드임베딩 기법으로 살핀 Song et al.(2020)은 /ㅁ/, /ㄷ/, /ㅈ/에 서 비정상적 비유창성 빈도가 높았음을 보고하기도 하였다. 이 러한 다양한 결과는 말자료를 수집하고 분석하는 방법의 차이 때문일 수도 있지만 말더듬는 사람마다 산출이 어려운 말소리 들이 서로 다르기 때문일 수도 있을 것이다.

최근에는 개별적인 말소리보다 낱말이나 어절 단위의 전체적인 조음·음운복잡성을 분석하는 방법을 사용하고 있다(Dworzynski \& Howell, 2004; Howell \& Au-Yeung, 2007; Lee et al., 2012). 특히 한국어의 경우 자발화에서의 조음·음운복잡성을 측정하기 위하여 어절을 언어학적 단위로 사용하고 있다(Kim \& Shin, 2020; Lee et al., 2004; Yoon et al., 2013). 조음·음운복 잡성은 개별 말소리의 다양한 특성뿐 아니라 음절의 구조 및 길이 등을 분석 기준에 반영하기 때문에 음성학적으로 복잡한 낱말/어절 산출과 SLD와의 관련성을 확인할 수 있다는 장점이 있다. 조음·음운복잡성 측정을 위해 사용되는 대표적인 지표 인 조음복잡성지표(index of phonetic complexity, IPC)는 분 절음의 음성학적 특징에 따라 0 점 혹은 1점을 부여한 후 총점 을 산출하는 방식으로 다양한 언어권에서 그 언어에 맞게 수정 하여 사용되었다(Dworzynski \& Howell, 2004; Howell \& AuYeung, 2007). 국내의 경우 Lee et al.(2004)이 한국어 특성에 맞게 수정 및 보완하는 과정을 거쳤으며 일반인뿐 아니라 의사 소통장애인의 조음·음운 특성을 파악하기 위하여 꾸준히 사용 되고 있다(Kim et al., 2017; Lee et al., 2012; Shin \& Ha, 2015). $\mathrm{IPC}$ 를 사용하여 조음·음운복잡성에 따른 말더듬 아동 및 성 인의 SLD 특성을 살핀 국내외 선행연구들은 SLD가 관찰된 낱 말/어절의 조음·음운복잡성이 유창하게 산출된 낱말/어절보 다 높았음을 일관되게 보고하였다(Dworzynski \& Howell, 2004; Howell \& Au-Yeung, 2007; Jung, 2005).

IPC 외에도 낱말/어절 단위의 조음·음운복잡성을 측정할 수 있는 지표로 평균음운길이(phonological mean length of utterance, PMLU)가 있다(Saaristo-Helin, 2009; Yoon et al., 2013). 대상자가 산출한 분절음과 정확하게 발음한 자음에 각
각 1점씩 점수를 부여하는 방식인 PMLU는 길이가 길고 음운 적으로 복잡한 낱말/어절의 특성이 점수에 직접적으로 반영된 다는 점에서 음절의 길이에 따라 0 점과 1 점을 이분법적으로 적 용하는 IPC와는 차이가 있다. 특히 길고 구문적으로 복잡한 발화에서 SLD가 더 빈번했다는 선행연구 결과를 고려한다면 (Chon \& Lee, 2019; Gaines et al., 1991; Logan \& Conture, 1995), PMLU가 SLD가 발생한 낱말/어절의 조음·음운복잡성 특성을 명확하게 반영할 수 있을 것이라는 예측이 가능하다. 하지만 PMLU는 주로 일반인 혹은 말소리장애인을 대상으로 사용되고 있으며(Flipsen et al., 2005; Yoon et al., 2013) 아직 까지 말더듬 장애에서는 제한적으로 사용되었다.

말더듬 장애 유무와 상관없이 모든 사람의 발화에서 관찰되 며 언어학적 비유창성으로도 불리는 가성비유창성(other disfluency, OD)은 언어를 계획하는 과정에서 발생하게 된다(Manning \& Shirkey, 1981). 내적수정가설은 SLD뿐만 아니라 OD의 발생도 동일하게 발화를 산출하기 전의 내면적 감독과정으로 인 하여 나타나게 된다고 설명한다(Kolk \& Postma, 1997; Postma \& Kolk, 1993). 그렇다면 SLD와 마찬가지로 길고 복잡한 발화 를 산출할 때 $\mathrm{OD}$ 또한 증가할 것으로 예측할 수 있다. 실제로 구문적인 측면에서 일반인의 발화를 분석한 결과 $\mathrm{OD}$ 가 발생한 발화가 유창한 발화보다 길이가 길고 구문적으로 복잡했음을 보고하였다(McLaughlin \& Cullinan, 1989). 말더듬 성인의 SLD 가 발생한 발화, $\mathrm{OD}$ 가 발생한 발화와 유창하게 산출된 발화의 평균형태소길이를 비교한 Chon \& Lee(2019) 역시 SLD가 발 생한 발화와 $\mathrm{OD}$ 가 발생한 발화가 유창한 발화보다 평균형태소 길이가 유의하게 길었음을 보고하여 내적수정가설을 지지하였 다. 하지만 음운적인 측면에서 $\mathrm{OD}$ 가 발생한 언어학적 단위, 즉 낱말이나 어절의 특성을 파악한 연구는 제한적이다. 특히 SLD 와 $\mathrm{OD}$ 가 모두 나타나는 말더듬 장애의 경우, 두 비유창성 범주 간 낱말/어절의 조음·음운복잡성 특성을 비교분석해 볼 수 있 을 것이다. Lee et al.(2004)의 경우 말더듬 아동과 말더듬 성인 의 읽기 발화에서 어절의 IPC 특성을 살펴본 결과 IPC가 높은 어절의 비유창성 빈도가 IPC가 낮은 어절의 비유창성 빈도보 다 높았다고 하였으나 비유창성을 SLD와 OD로 따로 구분해서 보고하지는 않았다. 따라서 말더듬는 사람을 대상으로 OD가 발생한 어절의 조음·음운복잡성이 SLD가 발생한 어절과 비슷 한 양상을 보이는지, 아니면 SLD와는 구별되는 양상을 보이는 지에 대한 연구가 필요하다. 또한 구조화된 상황에서 조음·음 운복잡성을 통제한 낱말이나 문장수준의 과제는 말더듬는 사 람의 비유창성 특성을 일반화하는데 한계가 있을 수 있기 때문 에 자발화 상황에서의 발화를 수집 분석할 필요가 있다.

따라서 본 연구는 SLD, OD 두 범주의 비유창성과 조음·음 운복잡성 간의 관련성을 파악하기 위하여 자발화 수준의 반구 
조화된 과제인 그림설명하기와 자연스러운 자발화 산출 상황 인 대화 과제에서 말더듬 성인의 발화를 수집하고 어절에 나타 난 비유창성 유무 및 범주에 따라 어절 유형을 분류하여 과제 및 어절 유형에 따른 조음·음운복잡성을 비교하였다. 조음·음 운복잡성 비교를 위하여 IPC와 PMLU 두 가지 지표를 모두 사 용하였으며, 두 지표점수 간 관련성을 살펴보았다.

\section{MATERIALS AND METHODS}

\section{연구 대상}

연구의 참여자는 만 18 세 이상의 말더듬 성인 32 명이었다. 본 연구를 위하여 1) 한국어를 모국어로 사용하며, 2) 자신이 말더 듬 문제가 있음을 인식하고 있고, 3) 국가자격증을 소지한 언어 재활사가 파라다이스-유창성검사-II(Paradise Fluency Assessment-II, P-FA-II) (Sim et al., 2010)를 사용하여 말더듬 중 증도를 평가한 결과 '약함' 이상의 중증도로 진단하였으며, 4) 말 더듬 외 말-언어문제를 동반하지 않으며, 5) 인지, 시각, 청각 및 신경학적인 문제가 없다고 보고한 참여자만을 선정하였다. 이 중 자발화 산출 과제인 그림설명하기와 대화 과제에서 본 연구 에서 사용하는 독립변수인 세 가지 어절 유형(유창한 어절, $\mathrm{OD}$ 어 절, SLD 어절)의 분석 조건이 모두 충족된 말더듬 성인 21명(남 성 18명, 여성 3명)을 최종 연구 참여자로 선정하였다. 최종 연구 참여자의 평균 연령은 29.86세( $\mathrm{SD}=9.58$, 범위 18 51세)였으며, P-FA-II를 사용한 말더듬 중증도는 중간 10 명, 심함 11 명이었다.

\section{자료 수집}

소음이 없는 조용한 공간에서 검사자가 연구 참여자의 발화 자료를 수집하였다. 그림설명하기 과제와 대화 과제에서 말더듬 성인의 발화를 각각 수집하기 위하여 P-FA-II의 필수과제 중 '말하기그림' 과제와 '대화' 과제를 사용하였으며, 발화자료 수 집 및 분석을 위하여 전 과정을 디지털카메라를 사용하여 녹화 하였다.

그림설명하기(말하기그림) 과제에서의 발화는 연구 참여자에 게 '공원' 풍경과 '시장' 풍경이 묘사된 그림판을 차례로 제시하 며 그림의 내용에 대해 자세히 이야기해 줄 것을 요청하여 수 집하였다. 또한 대화 과제를 위해 연구 참여자의 말더듬과 관련 된 질문을 포함한 일상적인 주제를 사용하여 자연스러운 의사 소통 상황에서의 발화를 수집하였다.

\section{자료 분석}

발화자료 전사 및 비유창성 분석

말더듬 성인에게서 녹화하여 수집한 그림설명하기 과제와 대
화 과제의 발화자료는 모두 음성전사를 실시하였다. 그 후 각 발화자료에서 관찰된 비유창성 분석을 실시하였다. 비유창성은 Yairi \& Ambrose(2005)의 기준을 따라 가성비유창성(OD)과 진성비유창성(SLD)의 두 범주로 나누었다. $\mathrm{OD}$ 에 포함된 비유 창성 유형은 간투사(삽입어), 미완성/수정, 구전체반복, 절전체 반복, 다음절낱말전체반복이었으며, SLD에 포함된 비유창성 유형은 일음절낱말반복, 낱말부분반복[part-word repetitions (PW): 다음절낱말일부반복, 음절반복, 음절부분반복, 말소리반 복], 비운율적 발성[disrhythmic phonation (DP): 막힘, 연장, 깨 진 낱말]이었다(Yairi \& Ambrose, 2005). 관찰된 모든 비유창 성 유형은 음성전사된 발화자료에 직접 기록하여 분석하였다. 또한 어절 단위 구분 및 어절 유형 분류 시 발생할 수 있는 오 류를 방지하기 위하여 반복이 나타난 경우 잉여적으로 산출된 단위반복은 괄호를 하여 표시하였다[예: (어린이가)어린이가, (안경)안경, (찍찍)찍고.

\section{어절 단위 구분 및 어절 유형 분류}

수집한 발화자료의 전사 및 비유창성 분석을 마친 후 조음. 음운복잡성을 측정하기 위하여 발화자료를 언어학적 단위인 어절로 나누었다. 어절 단위로 나누기 위하여 Yoon et al.(2013) 이 제시한 기준을 따랐다. $\mathrm{OD}$ 에 포함되지만 발화의 시작이나 중간에 '어', '그', '음과 같이 언어학적 의미를 내포하지 않고 단 독으로 산출된 '간투사(삽입어)' 유형과 낱말을 완전하게 산출 하지 않은 상태에서 산출을 중지하거나 곧바로 수정이 이루어 진 ‘미완성' 유형은 어절 단위 구분 시 제외하였다. 이러한 간투 사와 미완성은 낱말 단독으로 혹은 낱말에 조사가 붙어 만들 어지는 어절의 정의 및 형태(Yoon et al., 2013)에 포함될 수 없 기 때문이며, 어절의 조음·음운복잡성을 과소 측정할 수 있기 때문이다. 하지만 낱말이나 어절을 완전하게 산출한 이후에 발 화 산출을 중지하거나 수정이 이루어진 '미완성' 유형은 어절 단위 구분 시 포함하였다. 과제별로 발화를 어절 단위로 구분 한 이후 각 어절에 비유창성이 발생하였는지, 비유창성이 발생 하였다면 그 비유창성 유형이 속한 범주에 따라 어절을 세 가 지 유형으로 분류하였다: 1) 비유창성 없이 유창하게 산출된 어절은 '유창한 어절'에 포함하였으며, 2) 어절에 $\mathrm{OD}$ 범주에 포 함되는 비유창성 유형이 발생한 경우 ' $\mathrm{OD}$ 어절'에 포함하였다. 3) 마지막으로 어절에 SLD 범주에 포함되는 비유창성 유형이 나타난 경우, 'SLD 어절'에 포함하였다. 어절에 SLD에 포함되 는 비유창성 유형과 $\mathrm{OD}$ 에 포함되는 비유창성 유형이 함께 발 생한 비유창성군(disfluency cluster)의 경우 어절 유형 분류 시 제외하였다. 


\section{어절 유형별 어절 선정}

과제별로 각 어절을 세 가지 유형으로 분류한 이후 최종적으 로 IPC와 PMLU 분석에 포함시킬 어절을 선정하였다. Yoon et al.(2013)은 어절 선정 시 “동일한 어절은 1회만 선정(p.84)"하도 록 하였으나 본 연구의 경우 어절의 유형을 세 가지로 분류하였 기 때문에 동일한 어절이라 할지라도 비유창성 유무 및 범주에 따라 각 어절 유형에 1 회씩 포함하였다. 예를 들어, 연구 참여자 가 $[\mathrm{DP}$ 운동보글 이븐 남자가 달리기를 하고요 $\cdots \mathrm{PW}$ (나나)남자 가 점프슈슬 시도하고 이써요.]라고 발화를 산출하였다면, 처 음에 산출한 [남자가]는 유창한 어절에 포함하였으며, 이후 동 일한 어절을 산출하긴 하였으나 [(나나)남자가]라고 산출하여 어절에 낱말부분반복이 발생하였으므로 SLD 어절에 포함하였 다. 이후 '연구 참여자' 섹션에서 기술한 바와 같이 과제별로 각 어절 유형에 선정된 어절의 개수가 3 개 미만이 있는 경우 그 연 구 참여자의 자료는 분석에서 제외하였다. 연구 참여자마다 과 제와 어절 유형별로 IPC와 PMLU 분석을 위하여 선정한 어절 의 개수가 달랐고, 각 어절 유형의 IPC와 PMLU를 대표하는 값을 얻기 위하여 연구 참여자별로 평균값을 계산하였기 때문 이다(Chon et al., 2012; Chon \& Lee, 2016). 따라서 11명의 자 료를 분석에서 제외하였고 최종적으로 21명의 자료를 IPC와 PMLU 분석에 사용하였다. 그림설명하기 과제에서 선정된 유 창한 어절의 수는 평균 87.62개(SD = 26.29), OD 어절의 수는 평균 8.38개(SD = 3.67), $\mathrm{SLD}$ 어절의 수는 평균 12.43개(SD = 6.99)였다. 대화 과제의 경우, 유창한 어절의 수는 평균 100.33 개 $(\mathrm{SD}=36.31), \mathrm{OD}$ 어절의 수는 평균 6.95개(SD = 3.50), SLD 어절의 수는 평균 12.29 개( $\mathrm{SD}=13.07)$ 였다.

각 어절의 IPC와 PMLU를 분석하기 위하여 자음과 모음의 분류는 Kim \& Shin(2020)을 따라 자음 19개, 단모음 7개, 이중 모음 10 개를 적용하였다. 비유창성 중 '반복' 유형이 발생한 어 절의 $\mathrm{IPC}$ 와 $\mathrm{PMLU}$ 를 분석할 때 정상적인 발음이 나오기 전에 잉여적으로 되풀이한 단위 반복은 분석에 포함하지 않았다. 예 를 들어, [PW(나나)남자가]의 경우 [남자가]의 IPC와 PMLU를 분석하였다.

\section{조음복잡성지표 $(\mathrm{IPC})$ 분석}

과제별로 각 어절 유형에 포함된 개별 어절의 조음복잡성지 표(IPC)를 분석하였다. IPC는 Dworzynski \& Howell(2004)이 개발한 지표를 한국어에 맞게 수정 및 보완한 Lee et al.(2004) 의 IPC 기준을 따랐다. 즉, 개별 어절에 7개의 하위평가 지표인 '자음의 조음 위치', '자음의 조음 방법, '모음의 종류', '음절의 형태', '어절의 길이', '인접자음의 출현 여부, '인접자음의 조음 위치'를 각각 적용하여 초기에 발달하는 음성 특성인 경우 0 점 을 부여하고 상대적으로 후기에 발달하는 음성 특성인 경우 1
점을 부여하였다. 그 후 각 지표의 점수를 합산하여 개별 어절 의 IPC 점수를 산출하였다. 예를 들어, '자음의 조음 위치' 지표 의 경우, 양순음, 치경음, 성문음의 경우 초기에 발달하는 말소 리이므로 0 점씩을 부여하였고, 치경경구개음과 연구개음은 후 기에 발달하는 말소리이므로 1점씩을 부여하였다. 개별 어절의 IPC 점수를 모두 산출한 후, 각 과제 및 어절 유형별 평균 IPC 점수를 계산하였다.

\section{평균음운길이(PMLU) 분석}

PMLU 분석은 Saaristo-Helin(2009)이 제시한 분석법을 기 초로 하여 한국어 특성에 맞게 수정 및 보완하는 절차를 거친 Yoon et al.(2013)의 분석 기준을 따랐다. 대상자가 산출한 자 음과 모음에 1점씩 부여한 후 정확하게 발음한 자음에 1점씩을 추가하였다. 이중모음의 경우 활음에 1점씩 추가하였다. 하지만 자음이나 모음이 부적절하게 첨가된 경우 점수를 부여하지 않 았다(Yoon et al., 2013). IPC 분석과 마찬가지로 개별 어절의 PMLU 점수를 모두 산출한 후, 각 과제 및 어절 유형별 평균 PMLU 점수를 계산하였다.

\section{신뢰도 측정}

본 연구에서 독립변수 및 종속변수로 사용된 어절 선정 및 유형 판단(유창한 어절, $\mathrm{OD}$ 어절, $\mathrm{SLD}$ 어절), $\mathrm{IPC}, \mathrm{PMLU}$ 측 정에 대한 평가자 간 신뢰도를 측정하였다. 평가자 간 신뢰도는 연구자와 언어재활사 2 급 자격증을 소지하고 있으며 대학원에 서 유창성장애를 전공하고 있는 제 2 평가자에 의해 독립적으로 이루어졌다. 제 2 평가자는 연구자에게 말더듬 발화 전사 및 비 유창성 분석에 대한 훈련을 받았으며, 비유창성 분석 경험이 풍부한 평가자였다.

최종 분석에 포함된 연구 참여자 21 명의 약 $20 \%$ 인 4 명의 자 료를 무작위로 선정하여 어절 선정 및 유형 판단에 대한 일치 도를 구한 결과, 어절 선정은 그림설명하기 과제 $100 \%$, 대화 과 제 99\%였으며, 어절 유형 판단은 그림설명하기 과제 $99 \%$, 대화 과제 $99 \%$ 로 나타났다. Pearson 적률상관계수를 사용하여 각 과제 내 어절 유형별 IPC 점수와 PMLU 점수에 대한 평가자 간 신뢰도를 측정한 결과 그림설명하기 과제에서 $\mathrm{IPC}$ 의 경우, 유창한 어절 $0.99, \mathrm{OD}$ 어절 $0.96, \mathrm{SLD}$ 어절 0.99였으며, PMLU 는 유창한 어절 $0.99, \mathrm{OD}$ 어절 $0.99, \mathrm{SLD}$ 어절 0.99로 나타났 다. 대화 과제에서 $\mathrm{IPC}$ 는 유창한 어절 $0.99, \mathrm{OD}$ 어절 0.98 , SLD 어절 0.99 였으며, PMLU는 유창한 어절 $0.99, \mathrm{OD}$ 어절 0.94, SLD 어절 0.99로 나타났다.

\section{통계 분석}

통계분석은 IBM SPSS Statistics 26 (IBM Corp., Armonk, 
Table 1. Descriptive statistics (means \pm standard deviations) of IPC and PMLU in each type of eojeol in picture description and conversation tasks

\begin{tabular}{|c|c|c|c|c|c|c|}
\hline & \multicolumn{3}{|c|}{ Picture description } & \multicolumn{3}{|c|}{ Conversation } \\
\hline & Fluent eojeol & OD eojeol & SLD eojeol & Fluent eojeol & OD eojeol & SLD eojeol \\
\hline IPC & $4.40( \pm 0.35)$ & $3.72( \pm 0.76)$ & $4.75( \pm 1.05)$ & $4.53( \pm 0.55)$ & $3.78( \pm 0.97)$ & $5.41( \pm 1.30)$ \\
\hline PMLU & $10.22( \pm 0.45)$ & $8.06( \pm 1.54)$ & $10.76( \pm 2.07)$ & $10.50( \pm 0.70)$ & $8.48( \pm 2.09)$ & $11.93( \pm 2.01)$ \\
\hline
\end{tabular}

IPC: index of phonetic complexity, PMLU: phonological mean length of utterance, OD: other disfluency, SLD: stuttering-like disfluency

NY, USA)을 사용하여 실시하였다. 과제(그림설명하기, 대화)와 어절 유형(유창한 어절, OD 어절, SLD 어절)에 따른 IPC와 $\mathrm{PMLU}$ 를 비교하기 위하여 $2 \times 3$ 이요인 반복측정분산분석을 각각 실시하였다. 유의한 주효과가 발생한 경우, 최소유의차(least significant difference, $\mathrm{LSD}$ ) 사후검정을 실시하였다. 각 과제 및 어절 유형 내 IPC와 PMLU의 관련성을 분석하기 위하여 Pearson 적률상관분석을 실시하였다.

\section{RESULTS}

\section{과제와 어절 유형에 따른 IPC 비교 결과}

과제(그림설명하기, 대화)와 어절 유형(유창한 어절, $\mathrm{OD}$ 어절, $\mathrm{SLD}$ 어절)에 따른 평균 IPC는 Table 1과 Figure 1에 제시하였 다. 유창한 어절과 $\mathrm{OD}$ 어절의 경우, 과제 유형에 따른 평균 $\mathrm{IPC}$ 는 근소한 차이만을 보이는 것으로 나타났다. 또한 $\mathrm{OD}$ 어 절은 과제와 상관없이 평균 IPC가 가장 낮은 모습을 보였다. $\mathrm{SLD}$ 어절의 경우, 다른 어절 유형보다 높은 평균 IPC를 보였으 며 대화 과제가 그림설명하기 과제보다 평균 IPC가 상대적으 로 높은 경향을 나타냈다.

과제와 어절 유형에 따른 IPC의 차이를 확인하기 위하여 반 복측정분산분석을 실시한 결과, 과제와 어절 유형 간 상호작용 은 유의하지 않았다 $[\mathrm{F}(2,40)=2.04, p>0.05]$. 주효과 검정 결 과, 어절 유형에 따른 주효과는 통계적으로 유의하였으나 $[\mathrm{F}(2$, 40) $=23.16, p<0.001$, partial $\eta^{2}=0.54$ 과제에 따른 주효과 는 유의하지 않은 것으로 나타났다[F(1,20)=3.32, $p>0.05]$. 어절 유형에 따른 평균 IPC의 차이를 확인하기 위하여 LSD 사 후검정을 실시한 결과, SLD 어절의 IPC가 유창한 어절의 IPC $(p<0.01)$ 와 $\mathrm{OD}$ 어절의 IPC $(p<0.001)$ 보다 높아 어절 유형 중 IPC가 가장 높은 것으로 나타났다. 유창한 어절도 $\mathrm{OD}$ 어절 보다 높은 IPC를 보였다 $(p<0.001)$.

\section{과제와 어절 유형에 따른 PMLU 비교 결과}

과제와 어절 유형에 따른 평균 PMLU는 Table 1과 Figure 2 에 제시하였다. 과제 유형에 따른 평균 PMLU의 전반적인 패턴 은 IPC의 결과와 유사하게 나타났다. $\mathrm{OD}$ 어절이 과제와 상관 없이 평균 PMLU가 상대적으로 가장 낮은 것으로 나타났다.

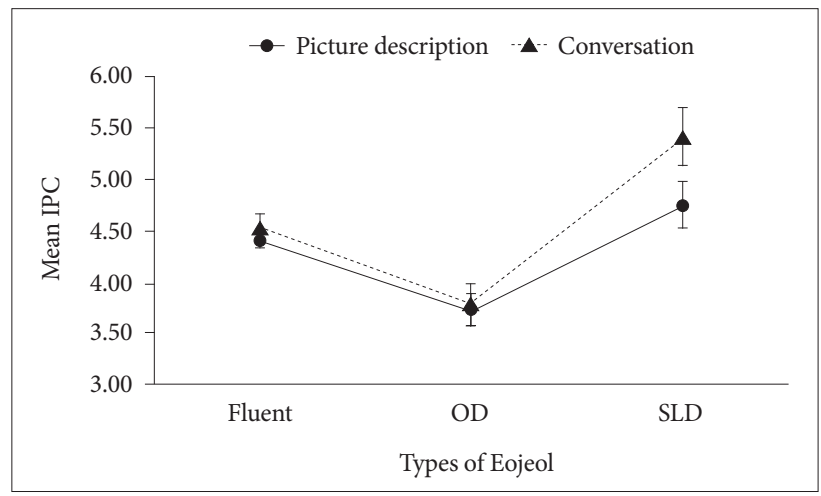

Figure 1. Mean IPCs ( \pm standard errors of the mean) of fluent, OD, and SLD eojeols in conversation and picture description tasks. IPC: index of phonetic complexity, OD: other disfluency, SLD: stutteringlike disfluency.

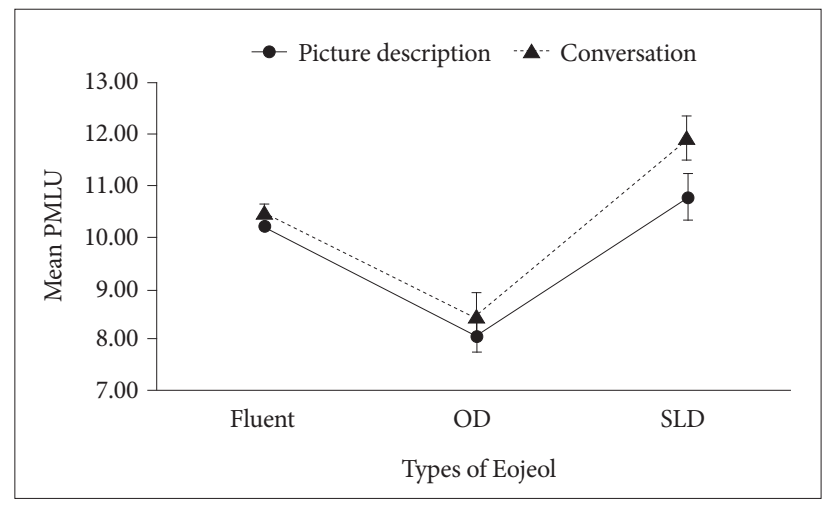

Figure 2. Mean PMLUs ( \pm standard errors of the mean) of fluent, $\mathrm{OD}$, and SLD eojeols in conversation and picture description tasks. PMLU: phonological mean length of utterance, OD: other disfluency, SLD: stuttering-like disfluency.

SLD 어절의 경우, 다른 어절 유형에 비해 상대적으로 높은 PMLU를 보였으며 그림설명하기 과제에 비해 대화 과제에서의 평균 PMLU가 상대적으로 높은 경향을 보였다.

과제와 어절 유형에 따른 PMLU의 차이를 확인하기 위하여 반복측정분산분석 실시하였다. Mauchly의 구형성검정 결과 어절 유형이 구형성 가정을 만족하지 못하였으므로 $[\mathrm{W}=0.65$, $\left.\chi^{2}(2)=8.18, p<0.05\right]$ Greenhouse-Geisser를 적용하여 분석 을 진행하였다. 분석 결과, 과제와 어절 유형 간 상호작용은 유 의하지 않았다 $[\mathrm{F}(1.63,32.67)=1.25, p>0.05]$. 주효과 검정 결 과, 어절 유형에 따른 주효과가 통계적으로 유의하였으나 
$\left[\mathrm{F}(1.48,29.63)=35.88, p<0.001\right.$, partial $\left.\eta^{2}=0.64\right]$ 과제에 따른 주효과는 유의하지 않았다 $[\mathrm{F}(1,20)=3.90, p>0.05]$. 어 절 유형에 따른 평균 PMLU의 차이를 확인하기 위하여 $\mathrm{LSD}$ 사 후검정을 실시한 결과, SLD 어절이 유창한 어절 $(p<0.05)$ 과 $\mathrm{OD}$ 어절 $(p<0.001)$ 보다 PMLU가 유의하게 높은 것으로 나타 났다. 유창한 어절 역시 OD 어절보다 PMLU가 유의하게 높았 다 $(p<0.001)$.

\section{자발화 과제 내 IPC와 PMLU 간 상관 결과}

각 자발화 과제에서 $\mathrm{IPC}$ 와 PMLU 간 상관분석을 실시한 결 과는 Table 2와 Table 3에 각각 제시하였다. 그림설명하기 과제 에서 어절 유형에 상관없이 IPC와 PMLU는 유의미한 상관을 보였다(Table 2). 특히 비유창한 어절 유형인 OD 어절과 SLD 어 절은 두 변수 간 높은 정적상관이 나타났으며 이는 통계적으로 도 유의하였다(OD 어절: $\mathrm{r}=0.795, p<0.001, \mathrm{SLD}$ 어절: $\mathrm{r}=$ $0.848, p<0.001)$. 유창한 어절의 경우, IPC와 PMLU 간 비교적 높은 정적 상관을 보였다 $(\mathrm{r}=0.495, p<0.05)$.

대화 과제도 그림설명하기 과제와 비슷한 결과를 보였다(Table 3). 즉, $\mathrm{OD}$ 어절과 $\mathrm{SLD}$ 어절은 IPC와 PMLU 간 높은 정적상 관을 보였으며 이는 통계적으로 유의하였다(OD 어절: $\mathrm{r}=0.813$, $p<0.001, \mathrm{SLD}$ 어절: $\mathrm{r}=0.862, p<0.001)$. 유창한 어절은 두 변수 간 비교적 높은 정적 상관을 보였다 $(\mathrm{r}=0.563, p<0.01)$.

\section{DISCUSSIONS}

본 연구는 말더듬 성인을 대상으로 하여 다양한 자발화 산

Table 2. The result of correlations between IPC and PMLU in each type of eojeol in picture description task

\begin{tabular}{lccc}
\hline \multirow{2}{*}{ IPC } & \multicolumn{3}{c}{ PMLU } \\
\cline { 2 - 4 } & Fluent eojeol & OD eojeol & SLD eojeol \\
\hline Fluent eojeol & $0.495^{*}$ & & \\
OD eojeol & & $0.795^{* * *}$ & $0.848^{* * *}$ \\
SLD eojeol & & & \\
\hline
\end{tabular}

${ }^{*} p<0.05,{ }^{* * *} p<0.001$. IPC: index of phonetic complexity, PMLU: phonological mean length of utterance, OD: other disfluency, SLD: stuttering-like disfluency

Table 3. The result of correlations between IPC and PMLU in each type of eojeol in conversation task

\begin{tabular}{lccc}
\hline \multirow{2}{*}{ IPC } & \multicolumn{3}{c}{ PMLU } \\
\cline { 2 - 4 } & Fluent eojeol & OD eojeol & SLD eojeol \\
\hline Fluent eojeol & $0.563^{* *}$ & & \\
OD eojeol & & $0.813^{* * *}$ & $0.862^{* * *}$ \\
SLD eojeol & & & \\
\hline
\end{tabular}

${ }^{* *} p<0.01,{ }^{* * *} p<0.001$. IPC: index of phonetic complexity, PMLU: phonological mean length of utterance, OD: other disfluency, SLD: stuttering-like disfluency
출 과제에서 발생한 비유창성 유무 및 범주에 따라 어절의 유 형을 유창한 어절, OD 어절, SLD 어절로 나누고, 과제와 어절 유형에 따른 조음·음운복잡성을 IPC와 PMLU를 사용하여 비 교·분석하였다. 연구 결과, 자발화 과제 유형과 상관없이 SLD 어절의 IPC가 유의하게 가장 높은 것으로 나타났으며, 유창한 어절의 $\mathrm{IPC}$ 가 $\mathrm{OD}$ 어절의 $\mathrm{IPC}$ 보다 유의하게 높았다. PMLU도 $\mathrm{IPC}$ 와 동일한 결과가 나타났다. 즉, SLD 어절의 PMLU가 모든 과제에서 통계적으로 유의하게 가장 높았으며, 그 다음으로 유 창한 어절, $\mathrm{OD}$ 어절의 순서였다. IPC와 $\mathrm{PMLU}$ 는 동일한 과제 및 어절 유형 내에서 유의한 정적상관을 보였으며, 유창한 어절 보다 비유창한 어절에서의 상관 정도가 더 높게 나타났다.

SLD 어절이 유창한 어절보다 조음·음운복잡성이 유의하게 높게 나타난 것은 선행연구를 지지하는 결과이다. 본 연구와 마 찬가지로 자발화를 사용하여 IPC를 측정하였던 연구들은 일관 되게 SLD가 발생한 낱말/어절의 조음·음운복잡성이 유창한 낱말/어절보다 유의하게 높았음을 보고하였다(Dworzynski \& Howell, 2004; Howell \& Au-Yeung, 2007; Jung, 2005). 또한 본 연구 결과는 조음·음운복잡성 정도(고, 저)에 따라 낱말 혹 은 어절을 분류하고 비유창성 빈도를 비교하였을 때 조음·음 운복잡성이 높은 낱말/어절일수록 비유창성 빈도가 높았음을 보고한 선행연구들(Lee et al., 2004; Lee et al., 2012)과도 맥 락을 같이 하고 있다. 조음·음운복잡성을 측정하는 또 다른 방법인 PMLU를 사용한 결과 역시 IPC와 동일하게 SLD가 발 생한 어절의 점수가 가장 높게 나타났다. 즉, SLD 어절은 다른 어절 유형에 비하여 어절의 길이가 길고 음운구조가 복잡했음 을 확인할 수 있었다. PMLU를 사용하여 비유창성 유무에 따 른 조음·음운복잡성을 살핀 연구는 제한적이다. 하지만 본 연 구의 결과는 IPC를 사용하여 조음·음운복잡성을 측정하였던 선행연구의 결과와 맥락을 같이한다고 해석할 수 있을 것이다. 따라서 IPC와 PMLU 지표의 결과를 모두 종합한다면 SLD가 발생한 어절은 다른 어절에 비해 길이가 길고 어절에 포함된 말 소리의 음성 특징 및 음절구조가 복잡하였다고 해석할 수 있 을 것이다. 이러한 SLD 어절의 특성은 서론에서 언급하였던 내 적수정가설을 지지하는 결과이기도 하다. 조음·음운적인 측면 에서 길고 발음하기 복잡한 어절 산출 시 말더듬는 사람의 음 성계획 과정에서 오류 발생의 가능성이 높으며 이러한 오류를 감지하고 내적 수정이 이루어지는 과정에서 SLD가 발생하였다 고 해석할 수 있기 때문이다.

$\mathrm{OD}$ 어절의 경우 자발화 과제와 상관없이 IPC와 PMLU가 가장 낮은 것으로 나타났다. 이러한 이유는 OD가 언어형성 및 인지처리 과정과 관련이 있는 언어적인 비유창성(Manning \& Shirkey, 1981)이기 때문인 것으로 보인다. OD 범주에 속하며 자발화에서 빈번하게 관찰되는 간투사(삽입어)의 경우(Yairi \& 
Ambrose, 2005) 본 연구의 어절 단위 구분 과정에서 제외되었 다. 간투사는 발화 내에 언어적인 의미를 지니고 있지 않거나 말하려는 내용과 상관없이 산출된 말소리 혹은 음절이었기 때 문에 어절의 정의 및 형태에 포함될 수 없기 때문이었다(Yoon et al., 2013). 간투사는 화자가 산출하고자 하는 발화를 계획하 거나 목표 낱말을 찾을 수 있는 시간을 확보하기 위하여 산출 하게 되는 비유창성이다(Clark \& Fox Tree, 2002; Oomen \& Postma, 2001; Watanabe et al., 2008). 일반인을 대상으로 간투 사의 특성을 연구한 결과, 간투사가 발생한 후에 산출된 발화는 그렇지 않은 발화보다 구문적으로 길었다고 하였다(Watanabe et al., 2008). 말더듬 집단에서도 유사한 결과가 나타났다. Ha $\& \operatorname{Sim}(2008)$ 은 말더듬 아동과 말더듬 성인집단 모두에서 간투 사가 발생한 발화가 간투사가 발생하지 않은 발화보다 길이가 길고 구문적으로 복잡하다고 하였으며, Chon \& Lee(2019) 역 시 간투사를 포함하여 $\mathrm{OD}$ 가 발생한 발화가 유창한 발화보다 구문적으로 더 길다고 보고하였다. 이러한 연구결과들은 간투 사의 특성 및 역할이 어절 단위가 아닌 발화 단위에서 분석이 이루어질 때 의미가 있음을 시사한다. 즉, 본 연구의 경우 간투 사가 제외되었으며, 간투사 이후에 산출된 발화가 어절 단위로 나뉘어져 분석이 이루어졌기 때문에 간투사의 역할이 드러나 지 않았다고 할 수 있을 것이다. 또한 OD 범주에 포함되는 다 른 비유창성 유형들 역시 음운적인 측면에서 어절의 단위로 분 석하는 것 보다는 발화 단위에서 언어학적 측면과 연결하여 분 석해야 할 필요가 있을 것으로 보인다. 내적수정가설 역시 어휘 적/의미적 측면이나 구문적인 측면에서의 오류가 감지될 때 이 를 내적으로 수정하는 과정에서 $\mathrm{OD}$ 범주에 속하는 비유창성 유형이 발생하게 된다고 설명하였다(Postma \& Kolk, 1993). 하 지만 간투사의 비포함을 전제로 음운적인 측면에서 어절 단위 의 조음·음운복잡성을 분석한 본 연구의 결과를 기준으로 하 였을 때, SLD가 발생한 어절과 OD가 발생한 어절은 서로 다른 조음·음운복잡성 특성을 가지고 있다고 할 수 있을 것이다.

PMLU는 자발화 상황에서 언어학적 단위의 음운적인 복잡 성을 확인할 수 있는 유용한 지표이다(Yoon et al., 2013). 본 연 구에서는 과제 및 어절 유형에 따른 평균 PMLU의 패턴이 IPC 와 매우 유사한 모습을 보였으며, 추리통계에서도 동일한 결과 를 나타냈다. 또한 동일한 과제 및 어절 유형 내에서 IPC와 PMLU가 유의한 정적 상관을 보여 말더듬는 사람의 조음·음 운복잡성을 측정할 수 있는 또 다른 지표가 될 수 있음을 확인 하였다. 다만 $\mathrm{IPC}$ 와 PMLU의 상관의 정도가 $\mathrm{SLD}$ 어절과 $\mathrm{OD}$ 어절에서는 높게 나타난 반면, 유창한 어절은 상관의 정도가 비 유창성이 발생한 어절보다는 상대적으로 낮게 나타났다. 이는 $\mathrm{SLD}$ 어절과 $\mathrm{OD}$ 어절의 경우, IPC와 PMLU 측정 시 반영하는 하위지표 및 점수 부여방식이 서로 다르지만 어절의 조음·음
운복잡성 특성이 유사하게 반영되었다고 생각해 볼 수 있다. 반 면, 유창한 어절의 경우 연구 참여자별로 어절의 길이나 음운구 조의 복잡성, 그리고 분절음의 음성학적 특성이 비유창한 어절 보다 상대적으로 다양했던 것으로 보인다. 따라서 IPC와 PMLU 에서 반영하게 되는 하위지표 및 점수 부여방식에 따라 비유창 한 어절보다는 상대적으로 다양한 점수가 산출되었던 것으로 해석할 수 있다.

본 연구는 말더듬 성인을 대상으로 일반적인 발화 산출 상황 인 자발화 과제를 통해 진성비유창성이 발생한 어절, 가성비유 창성이 발생한 어절과 유창한 어절의 조음·음운복잡성을 비 교·분석하였다. 또한 국내에서 말더듬는 사람의 조음·음운복 잡성 측정을 위해 주로 사용되는 IPC 뿐만 아니라 PMLU를 함께 사용하여 말더듬 성인의 조음·음운복잡성 특성을 확인 하였다. 후속연구에서는 본 연구의 결과가 말더듬 아동에게도 동일하게 적용되는지 살펴볼 수 있을 것이다. 말더듬 성인의 경 우 말더듬이 지속되어 만성화 되었으며 언어 및 말소리 발달이 완료되었으나 말더듬이 시작된 이후 지속기간이 짧고 언어발달 과 말소리발달이 이루어지고 있는 시기의 아동의 경우 본 연구 의 결과와 다른 조음·음운복잡성 특성을 보일 수도 있기 때문 이다. 또한 본 연구는 비유창성 범주(SLD, OD)에 따른 조음. 음운복잡성 특성을 비교하기 위한 목적으로 비유창한 어절을 $\mathrm{SLD}$ 어절과 $\mathrm{OD}$ 어절로 분류하였으며, SLD와 OD가 함께 발 생한 어절은 분석에서 제외하였다. 하지만 SLD에 속하는 비유 창성 유형과 $\mathrm{OD}$ 에 속하는 비유창성 유형이 함께 발생한 비유 창성군의 경우 단일 비유창성이 발생한 경우와는 다른 조음. 음운복잡성 특성을 가지고 있을 수 있을 것이다. 따라서 후속 연구에서는 비유창한 어절의 조음·음운복잡성 특성을 보다 포괄적으로 파악하기 위하여 SLD 어절과 OD 어절뿐만 아니 라 $\mathrm{SLD}+\mathrm{OD}$ 비유창성군 어절을 따로 어절 유형으로 분류하 여 분석할 수 있을 것이다. 마지막으로 말더듬는 사람의 외현적 인 말더듬 중증도에 따른 유창한 어절과 비유창한 어절의 조 음·음운복잡성 특성을 파악하는 후속 연구가 이루어진다면 $\mathrm{SLD}$ 가 발생하는 조음·음운 환경에 관한 심도 있는 논의가 가 능할 것으로 보인다.

중심 단어 : 비유창한 어절, 조음복잡성지표, 조음·음운복잡성, 평균음운길이, 말더듬.

\section{Ethical Statement}

This study was approved by the Institutional Review Board of Chosun University (2-1041055-AB-N-01-2013-0005).

\section{Acknowledgments}

The author thanks to the participants. 


\section{Declaration of Conflicting Interests}

There are no conflict of interests.

\section{Funding}

This study was supported by research fund from Chosun University in 2018.

\section{ORCID iD}

HeeCheong Chon https://orcid.org/0000-0002-9715-7164

\section{REFERENCES}

Chon, H. \& Lee, S. (2016). Effects of stuttering severity on articulation rate in fluent and dysfluent utterances of preschool children who stutter. Phonetics and Speech Sciences, 8(3), 79-90.

Chon, H. \& Lee, S. B. (2019). Characteristics of speech rates and utterance lengths in fluent and disfluent utterances of adults who stutter. Audiology and Speech Research, 15(3), 214-222.

Chon, H., Sawyer, J., \& Ambrose, N. G. (2012). Differences of articulation rate and utterance length in fluent and disfluent utterances of preschool children who stutter. Journal of Communication Disorders, 45(6), 455467.

Clark, H. H. \& Fox Tree, J. E. (2002). Using uh and um in spontaneous speaking. Cognition, 84(1), 73-111.

Dworzynski, K. \& Howell, P. (2004). Predicting stuttering from phonetic complexity in German. Journal of Fluency Disorders, 29(2), 149-173.

Felsenfeld, S., Kirk, K. M., Zhu, G., Statham, D. J., Neale, M. C., \& Martin, N. G. (2000). A study of the genetic and environmental etiology of stuttering in a selected twin sample. Behavior Genetics, 30(5), 359-366.

Flipsen, P., Hammer, J. B., \& Yost, K. M. (2005). Measuring severity of involvement in speech delay: Segmental and whole-word measures. American Journal of Speech-Language Pathology, 14(4), 298-312.

Gaines, N. D., Runyan, C. M., \& Meyers, S. C. (1991). A comparison of young stutterers' fluent versus stuttered utterances on measures of length and complexity. Journal of Speech, Language, and Hearing Research, 34(1), 37-42.

Ha, J. W. \& Sim, H. S. (2008). A comparison study of interjectional characteristics between people who stutter and people who do not stutter. Korean Journal of Communication Disorders, 13(3), 438-453.

Howell, P. \& Au-Yeung, J. (2007). Phonetic complexity and stuttering in Spanish. Clinical Linguistics and Phonetics, 21(2), 111-127.

Jung, Y. (2005). Disfluency and phonological features in the spontaneous speech of preschool children Who stutter (Unpublished master's thesis). Seoul: Yonsei University.

Kim, A. R., Lee, R., Han, J. S., \& Lee, E. J. (2017). Phonological characteristics of 4- to 5-year-old children in nonword repetition under different phonetic complexity. Communication Sciences and Disorders, 22(3), 445-457.

Kim, S. J. \& Shin, J. Y. (2020). Speech Sound Disorders. (2nd ed.). Seoul: Sigma Press.

Kolk, H. \& Postma, H. (1997). Stuttering as a covert repair phenomenon. In Curlee, R. F. \& Siegel, G. M. (2nd ed.). Nature and Treatment of Stuttering: New Directions (pp. 182-203). Boston: Allyn \& Bacon.

Kwon, D. (1991). The onset of stuttering behaviors (2): In the phonological aspects of language contexts. Journal of Speech-Language \& Hearing Disorders, 1, 147-165.

Lee, E. J., Han, J. S., \& Sim, H. S. (2004). The effects of the phonetic complexity on the disfluencies and the articulation errors of people who stutter. Communication Sciences and Disorders, 9(3), 139-156.

Lee, S. Y., Sim, H. S., Shin, M. J., \& Lee, S. B. (2012). The influence of phonological complexity on the naming ability of preschool-age children who stutter. Communication Sciences and Disorders, 17(2), 219-233.

Logan, K. J. \& Conture, E. G. (1995). Length, grammatical complexity, and rate differences in stuttered and fluent conversational utterances of children who stutter. Journal of Fluency Disorders, 20(1), 35-61.

Ludlow, C. L. \& Loucks, T. (2003). Stuttering: A dynamic motor control disorder. Journal of Fluency Disorders, 28(4), 273-295.

Manning, W. \& Shirkey, E. (1981). Fluency and the aging process. In Beasley, D. S. \& Davis, G. A. Aging, Communication Processes and Disorders (pp. 175-189). New York, NY: Grune \& Stratton.

McLaughlin, S. F. \& Cullinan, W. L. (1989). Disfluencies, utterance length, and linguistic complexity in nonstuttering children. Journal of Fluency Disorders, 14(1), 17-36.

Oomen, C. C. E. \& Postma, A. (2001). Effects of divided attention on the production of filled pauses and repetitions. Journal of Speech, Language, and Hearing Research, 44(5), 997-1004.

Postma, A. \& Kolk, H. (1993). The covert repair hypothesis: Prearticulatory repair processes in normal and stuttered disfluencies. Journal of Speech, Language, and Hearing Research, 36(3), 472-487.

Saaristo-Helin, K. (2009). Measuring phonological development: A followup study of five children acquiring Finnish. Language and Speech, 52(1), 55-77.

Sheehan, J. G. (1974). Stuttering behavior: A phonetic analysis. Journal of Communication Disorders, 7(3), 193-212.

Shin, G. E. \& Ha, J. W. (2015). The effects of phonetic complexity on the disfluency and articulation errors of children with speech sound disorders. Journal of Speech-Language and Hearing Disorders, 24(1), 91-102.

Shin, M. (1996). Characteristics of fluency disorders. Speech-Language Disorder Research, 1, 82-103.

Sim, H., Shin, M., \& Lee, E. (2010). Paradise Fluency Assessment-II. (2nd ed.). Seoul: Paradise Welfare Foundation.

Smith, A. \& Kelly, E. (1997). Stuttering: A dynamic, multifactorial model. In Curlee, R. \& Siegel, G. (2nd ed.). Nature and Treatment of Stuttering: New Directions (pp. 204-217). Needham Heights, MA: Allyn \& Bacon.

Song, S., Chon, H., \& Lee, S. B. (2020). Analyzing the disfluency of reading tasks of persons who stutter based on deep learning and word embedding. Communication Sciences and Disorders, 25(3), 721-737.

Watanabe, M., Hirose, K., Den, Y., \& Minematsu, N. (2008). Filled pauses as cues to the complexity of upcoming phrases for native and non-native listeners. Speech Communication, 50(2), 81-94.

Yairi, E., Ambrose, N., \& Cox, N. (1996). Genetics of stuttering: A critical review. Journal of Speech, Language, and Hearing Research, 39(4), 771784.

Yairi, E. \& Ambrose, N. G. (2005). Early Childhood Stuttering for Clinicians by Clinicians. (1st ed.). Austin, TX: Pro-Ed.

Yoon, M. S., Kim, J. M., \& Kim, S. J. (2013). Phonological whole-word measures of spontaneous speech in children two to four years of age. Journal of Speech-Language and Hearing Disorders, 22(4), 69-85. 